УДК 821.161.2-94.09 С. Єфремов

Галич Олександр, доктор філологічних наук, професор, професор кафедри державного управління, документознавства та інформаційної діяльності

Національний університет водного господарства та природокористування (м. Рівне)

\title{
СПЕЦИФІКА ВІДТВОРЕННЯ ЗОВНІШНОСТІ ТА ВНУТРІШНЬОГО СВІТУ РЕАЛЬНОЇ ОСОБИ В СПОГАДАХ С. ЄФРЕМОВА
}

\begin{abstract}
У статті з'ясовуетъся специфіка портретування реалъной особистості в спогадах С. Єбремова. Розкриваютъся особливості створення автором розгорнутих портретів земляків із Звенигородщини, а також визначних діячів украӥнсъкоӥ літератури та кулътури, з якими особисто був знайомий автор. Творчу уяву, домисел $і$ вимисел мемуарист намагаетъся мінімізувати, ніби прагнучи, щоб читач мав можливість якомога повніше осмислити постать реальноӥ особи, героя спогадів.
\end{abstract}

Ключові слова: щоденникові записи, портрет, розгорнутий портрет, хода, поза, костюм, міміка.

Halych O. A. Specification of realization of external and internal of real person's world in the memoirs of S. Yefremov.

Serhiy Yefremov is one of the greatest Ukrainian literary scholars of the first decades of the twentieth century. His scholarly work began when Ivan Franko was still in power, and Mikhailo Hrushevsky became mature, and Mykola Yevshan was rapidly expanding. The article deals with the memoirs of S. Yefremov "Pro dni mynuli", which appeared only in 2011. The author on the foreground makes the problem far from paramount, but clearly identifies the potential of the author of memoirs as a wonderful physiognomist, a person who can recognize the mental state of the hero of memoirs, his inner world in appearance and facial expressions. These are the features of portraiture in the memoirs of S. Yefremov. Most often, this author uses an expanded portrait of a real hero, which consists of several paragraphs and can be static, that is, concentrated in one place of the work or dynamic, scattered by separate splashes in different places. Portrait of S. Yefremov is created on the basis of personal impressions in communication of the author with real heroes, fellow villagers, family members, friends, acquaintances, but always complemented by certain weighty details that make the personality figure more voluminous, psychologically motivated. The creative imagination, deliberation and fiction the memoirist tries to minimize, as if striving, so that the reader has the opportunity to fully comprehend the figure of a real person, a hero of memoirs, among which there are quite well-known personalities in the history of Ukrainian culture (I. Nechui-Levytsky, O. Konysky, V. Antonovich). 
28 Літератури світу: поетика, ментальність і духовність. 2020. Bип. 14

Key words: diary entries, portrait, detailed portrait, stroke, posture, costume, facial expressions.

Постановка проблеми. Сергій Олександрович Єфремов - один із найбільших українських літературознавців перших десятиліть XX століття. Його наукова діяльність розпочиналася тоді, коли ще в силі був Іван Франко, набував зрілості Михайло Грушевський, стрімко входив Микола Євшан. С. Єфремов - виходець із духовного середовища, його батько тривалий час був сільським священиком у с. Пальчик, що на Звенигородщині (зараз це Черкаська область). Сам же майбутній науковець мав духовну та світську освіту: Уманська бурса, Київська духовна семінарія, Київський університет святого Володимира. Його наукові інтереси були різнобічними. Слід відзначити монографічні дослідження творчості Марка Вовчка (1907), Тараса Шевченка (1914), Івана Франка $(1913,1926)$, Михайла Коцюбинського (1922), Івана Нечуя-Левицького (1924), Івана Карпенка-Карого (1924), Панаса Мирного (1928). Його перу належить грунтовне історико-літературне дослідження, присвячене еволюції української літератури, доведене ним до початку минулого століття, «Історія українського письменства» (1911). Нас же цікавить мемуарна творчість С. Єфремова. Про його щоденник 20-х років, оприлюднений 1997 року, уже не раз писали дослідники. Однак щоденникові записи 1895-1896 рр. відомі набагато менше. Так само досі не отримали належної оцінки його спогади «Про дні минулі», що з'явилися друком лише 2011 року. Писалися вони 1920-1921 років, коли науковець ще перебував на нелегальному становищі, переховуючись від радянської влади поблизу Києва та й у самому місті, поки у квітні 1921 року не був амністований, одержавши охоронну грамоту від керівника тодішнього українського більшовицького уряду $\mathrm{X}$. Раковського. Мемуари виявилися незакінченими, їхні події закінчуються 1906 роком i після переходу на легальне становище не були вже продовжені автором.

Співзвучні до спогадів С. Єфремова твори Є. Чикаленка, Д. Дорошенка, О.Лотоцького все ж програють першим. Мемуари «Про дні минулі» явно глибші, художніші за них, а в чомусь і документальніші, хоча в них йдеться про одну й ту ж добу в історії України. Передусім твір С. Єфремова надзвичайно поліфонічний: він розкриває еволюцію особистості вченого в умовах Російської імперії

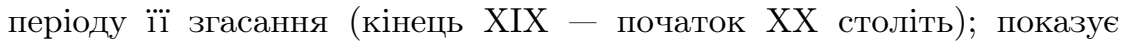
як поступово все більше інтелігентів відчували себе українцями; 
аналізує процеси зародження української преси, створення першого українського видавництва «Вік», відтворює боротьбу молодих українських партій, пошуки ними спільних позицій в умовах жорсткого протистояння 3 відверто проросійськими силами. Крім того в спогадах С. Єфремова помітне місце посідає українське село, зокрема його батьківщина Пальчик, що на Звенигородщині, відображена схоластика тогочасної освіти в Уманській бурсі та Київській семінарії, неприглядність служби в тогочасній російській армії, затхла атмосфера царських тюрем. Всі ці проблеми є актуальними при аналізі мемуарів С. Єфремова. Проте автор на перший план виносить проблему далеко не першорядної актуальності, однак таку, що виразно окреслює потенціал автора спогадів як чудового фізіономіста, людини, яка може розпізнавати за зовнішністю й мімікою обличчя психічний стан героя спогадів, його внутрішній світ. Мова йде про особливості портретування в мемуарах С. Єфремова. Його твір насичений портретними характеристиками десятків реальних особистостей, зокрема діячів українського визвольного руху, селян, духовенства, меценатів, офіцерів царського війська, поліцейських, наглядачів у тюрмах тощо.

Аналіз останніх досліджень і публікацій з теми. Проблема портретування в українському літературознавстві далеко не нова. Стосовно художньої літератури іï успішно розробляли М. Габель, I. Семенчук, К. Сізова, Н. Копистянська. А. Галичу належить дослідження, присвячене специфіці портретування в документальному тексті. У розділі «Структура портрета в документальному тексті» згаданий науковець виділяє такі різновиди портрета, як лаконічний, короткий, розгорнутий портрети, автопортрет, парний та колективний портрети, а також оніричний портрет. Всі ці різновиди (за винятком хіба що оніричного) присутні в мемуарах С. Єфремова. Однак цей автор надає перевагу розгорнутим портретам. На погляд А. Галича, «розгорнутий портрет складається з кількох абзаців $i$ дуже рідко $\epsilon$ статичним, концентрованим у одному місці твору. Він здебілъшого постае деконцентрованим, розкиданим по всъому тексту твору, особливо в текстах художнъої біографіï» [1, с. 154].

Мета статті. Автор дослідження прагне проаналізувати своєрідність портретування реальних особистостей в мемуарах С. Єфремова, віддавши перевагу специфіці створення розгорнутих портретів героїв.

Виклад основного матеріалу. У мемуарах С. Єфремова розгорнутий портрет яскраво представлений у перших розділах, де 
автор відтворює риси зовнішності, розкриває внутрішній світ своїх односельців: Марійки Кордюченкової, Микити і Павла, братів Андрія та Ониська, Грицька Вовка, старого П'ятковського, Парасича, Парія, Танасія Крамаренка, громадського пастуха Пугача, голів єврейських родин Мошка, Алтера та Гейне та інших мешканців Пальчика. Той факт, що далеко не у всіх мешканців Пальчика названі їхні прізвища, зайвий раз потверджують специфіку мемуарів. Вона пов'язана 3 пам'яттю людини. Твір С. Єфремова писався через багато років після подій, а тому автор міг забути окремі прізвища своїх героїв.

Складниками портретної характеристики односельців С. Єфремова виступають хода, поза, погляд, костюм, жест, міміка тощо. Так, репрезентуючи зовнішній вигляд i внутрішній світ Марійки Кордюченкової, автор спогадів спочатку ніби представляє героїню і лише потім звертає увагу на її зовнішність, поставу, особливості ходи, вбрання: «Осъ Марійка Кордюченкова, по-вуличному Гондзюрка, жвава, метка, дотепна, хоч $і$ занадто часом балакуча та лепетлива бабуся, на всі руки майстер - швачка, куховарка, господиня. Вона була немов членом нашої родини... . . . Як зараз бачу ї̈ низъку, трохи зігнуту постать, що наче трохи підскакуе ходячи, з незмінними окулярами на лобі, поверх чорної злинялої хустки, зав'язаноӥ зверху» [2, с. 193]. Далі мемуарист звертає увагу на специфіку їі мовлення, роблячи акцент на тяжінні цієї жінки до пліткарства. Маючи добре підвішений язик, Марійка часом розуміла, що бовкнула зайве, тоді вона намагалася стати улесливою: «Дуже добра оповідачка, вона нікого, ніже навіть самого суворого “батюшку", не обминала своїм гострим язичком, хоча зараз же, по прикрій правді, могла прохопитися $і$ якимсь улесливим словечком. . . В ній була якась дивна мішанина природної сміливості й гостроти з дворацькою угодністю та облесністю, розуму з легковажністю, поваги з блазенством. На язик гостра, мов бритва, могла иноді бовкнути якусь несосвітенну дурницю, але з такою добродушною усмішкою, що не розбереш було, чи це навмисне, з якогось химерного лукавства, чи просто так сказалосл, вилетіло з уст. Плетуха, вона переносила всі плітки й новини й була немов повітовою газетою, бо жодна оказія в околиці по попівсъких домах не обходилась без Марійки» [2, с. 193-194]. Авторові спогадів подобалася Марійка як чудова оповідачка, що могла не лише розповідати різні цікаві історії, а імітувати голоси їхніх персонажів: «Я особисто любив слухати ї̈ оповідання про старовину, а ще більше казок, яких вона розказувала з смаком, підробляючись голосом до персонажів, допомагаючи вражінню відповідними модуляціями та 
драматичними жестами» [2, с. 194]. Згадуючи зовнішній вигляд цієї жінки, С. Єфремов затруднявся з визначенням її віку: «Скільки ій тоді було літ - я не сказав би: з вигляду могло бути $і$ сорок, i шістдесят, але дорослі вже діти свідчили, що певніше останне. Вона якось потім затужавіла, і вже майже не мінялась - скільки ï̈ пам'ятаю, все була майже однакова...» [2, с. 194]. Мемуаристу довелося пізніше бачитися з цією героїнею, і вона йому розповіла, «що була осліпла, але як я зустрівся з нею, то вже знов бачила після операцї̈ й поводилась з звичайною енергією» [2, с. 194]. Портретну характеристику Марійки автор закінчує словами: «Я нітрохи б не здивувався, коли б почув, що Марійка жива й досі і так само править у повіті за газету, за куховарку, за швачку, за неодмінного учасника всяких оказій» $[2$, с. 194].

Із близьких людей найцікавішим є портрет матері С. Єфремова Дарії Дмитрівни (дівоче прізвище Крамаренко): «Душею нашої сім'’ була, власне, мати, $i$ хоч ї̈ особисте життя було тяжке, часто надто тяюкее, але сім'ю вона зберегла $i$ на всіх дітей своїх мала такий вплив, який не обмежуеться самими дитячими роками, а вистарчає, певне, довіку» [2, с. 218]. Представляючи портретні риси матері, С. Єфремов акцентує увагу читачів на зовнішності героїні, виділяючи окремі її деталі, а саме: колір очей та волосся, задумливий погляд, моложаве обличчя: «Коли я згадую про матір з тієї пори свого дитинства, то я завжди уявляю собі високу, гарну, здорову жінку з карими затуманеними очима й молодим обличчям у сріблястій короні чілком білого волосся. Справді, - ій було тоді тридиять з чимось років, але волосся мала сиве, як у старої людини, і ие при тихому сяйві задуманого погляду й моложавому обличчі надавало ій якогось небуденного, ефективно-поважного вигляду. Я не знаю, чому вона такою молодою - тридияти років - посивіла. Але коли я думаю, $і$ що більше думаю над ї̈ долею, то дужче впадае мені на думку ия символічність молодого обличчя в срібному вінку старости. Величезний тягар, який двигала на собі мати цілий вік свій, двигала без нарікання, без утоми, з якоюсь самопожертвою, остаючись завжди молодою й одзивною духом, $i$ ті вічні розлуки з дітъми, за яких завжди щосъ рідного і близъкого одривається од сери,я, все че так пасуе до тієї сильної постати з молодим обличчям у срібній короні. Молодість і досвід, сила і терпіння» [2, с. 219]. Портрет подано в діалектичному розвитку. Автор прагне показати, як із віком змінюється зовнішність дорогої йому людини. Мемуарист знову вдається до акцентування уваги на окремих деталях зовнішності, 
32 Літератури світу: поетика, ментальність $і$ духовність. 2020. Bип. 14

зокрема на очах і волоссі: «Потім постаріло й злиняло $i$ це дороге обличчя, погасли блискучі очі - це на очах у мене діялось, $і$ з кожним приїзом помічав я, як занепадають сили, на очах у мене й зовсім порвалося ие дороге мені життя, - але й тепер у моїх думках $i$ в моїх споминах стоїт молоде свіже обличчя в срібній короні важкой коси, що обвивала вродливу голову. (Портрети, що лишись по ній, не передають усієї принадності живого образу)» [2, с. 219].

Завершується портретна характеристика матері героя коротким підсумком її життя на тлі суспільної атмосфери часу: «Мати моя була, не скажу - свята, але, безперечно, сильна $i$ горда жінка, не зовсім звичайна типом у тій сіренькій атмосфері, в яку втиснуло ї̈ життя. Ранне заміжжжя, дрібні діти, величезний тягар родинний, що падав на неї й тілъки на неї, хатній клопіт і всі обставини дрібного жсивотіння не пригасили в ній того потягу до чогось вищого, небуденного, якихось неясних, може, проте дужих поривів, що безпечно, в ній жили $i$ давали, може, спочинок, а може, й зайвої туги підливали в тяжке життя» [2, с. 219].

Проте на цьому портрет матері не закінчується, автор ще кілька разів його уточнюе. Він пригадує, що мама «гарно співала, знала силу пісень і любила співи. Оповідання ї раз у раз були образні, колоритні, характеристики влучні, а мова жива, повна яскравих прикладів та прислів $\dddot{в}$, - говорю, звичайно, про українсъку мову, бо російсвкою при оказіях вона говорила хоч $i$ досить чисто, але иілком механічно, як $i$ більшість в їі стані людей» [2, с. 219]. А ще мама «любила за роботою слухати книжку, і мені самому довелося перечитати з нею мало не всю українсъкі літературу й багато з російсъкої - $i$ вона тонко розуміла читане, пам'ятала й оцінювала. . . [2, с. 219-220].

Не менш цікавими є портрети знаних в Україні людей. С. Єфремов відтворює риси зовнішності багатьох українських політичних діячів, письменників, музикантів, меценатів. Зосередимо увагу на портретах деяких з них. Характерним є опис зовнішності класика української літератури I. Нечуя-Левицького. Мемуарист чітко означує дату свого знайомства з письменником: «Перша моя літературна знайомість була з Ів[аном] Сем[еновичем] Левицьким-Нечуєм. Було ие, мабуть, у кіниі 1892 року. Я саме перед тим поперечитував, та й не раз - $i$ для себе, $і$ з матір'ю, і з сільсъкими товаришами та знайомими доступні мені твори Левицького, $i$ вони зробили на мене надзвичайне вражіння $і$ яскравістю, прозорістю малюнку, манерою писъма $і$ самою навіть мовою» [2, с. 370]. Знайомство з класиком було важливе для С. Єфремова ще й тому, що його батько навчався з I. Нечуєм-Левицьким 
у духовній семінарії, з матір'ю той був також знайомим і «навіть таниював на одному балю» [2, с. 371].

Автор мемуарів згадує свій стан, коли товариш вів його до будинку письменника: «Серце у мене сильно колотилося, коли я з Кедреновсъким увійшов у двір $i$ попростував до ґаночка малого флігелька, що стояв серед двору. Потім я часто сюди ходив $i$ один, $i$ водячи таких само новаків-пілігрімів, яким того разу був сам, $i$ кожнного разу згадував отой перший свій візит до писъменника. . . .

Двері були не замкнені, - i ми увійшли в малесенький передпокій, половина якого завалена була зв'язками книжск. 3-за дверей почувся тихий голос - "хто там", потім дрібна хода, і на порозі стала маленька постать дідуся в темно-синъому халаті, з-за якого виглядали білі комірчики й чорний галстук. Лище трохи сухе, але привітне, маленъка шпаковата борідка $i$ акуратний проділ через усю голову. Так оце він - Іван Семенович! - думав я, поки мій товариш здоровкавсь з писъменником $i$ знайомив мене $з$ ним. Я уявляв його собі інакше - великим кремезним чоловіком, a він, бач, такий мінвятюрний та акуратний... Він справді робив вражіння мінъятюрности та акуратності. I все навкруги його так само. Міньятюрні дві світлички, маленъка етажерка з книюками, маленький столичок перед маленькою канапкою, $i$ маленька постать господаря так пасувала до иих обставин, мінъятюрности й акуратності, що розлиті були по цих чистеньких, ясних покоїках» [2, с.371]. Специфікою цього опису є те, що автор поєднує портрет з інтер'єром. I лише потім робить акцент на власне портреті І. Нечуя-Левицького, манері його спілкування, зовнішньому вигляді, особливостях мови: «Ми всі розмовляли хоч і по-украӥнському, але з домішкою чужих слів, - "семінарсъким жсаргоном", $i$ вперше почув я чисту, образну, бездоганну українсъку мову в Київі. Це була мова «Кайдашевої сім' '̈», «Бурлачки», "Хмар», плила рівно, як музика, $i$ чарувала тими несподіваними модуляиіями, які вражають вас у розмові проти селянсъких бабів» [2, с.372]. С. Єфремов сподівався побачити в постаті I. Нечуя-Левицького людину величну, натомість побачив звичайну людину в халаті, що говорила про буденні речі, а не пророчила.

Автор спогадів не раз потім бував в оселі I. Нечуя-Левицького. Портрет старого письменника обростав новими деталями. С. Єфремов уважав, що його час залишався в минулому, «а він иъого не розумів $i$ акуратно писав нові речі, вже нікому не потрібні, так само поправляв на гірше старі й був живим образом боротьби поколіннів. 
34 Літератури світу: поетика, ментальність $і$ духовність. 2020. Bип. 14

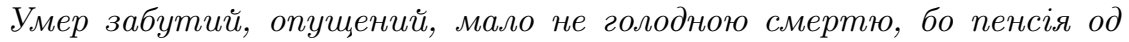
українсъкого уряду забариласъ $i$ не піддержала цього життя, колись такого помітного за часів неволі й німування. Пережив себе старий, а нема, може, гіршого лиха, як пережити себе...» [2, с. 373].

3 інших українських письменників С.Єфремов репрезентує розгорнутий портрет Олександра Кониського. Автор спогадів розпочинає цей портрет з того, що наводить власне уявлення про особу письменника, а потім нотує свої враження після першого знайомства: «Господар спершу здавсь мені був кремезним, трохи суворим дідусем $з$ слідами хвороби на жовтому обличчі: вже й тоді бували у його напади ядухи, хвороби, од якої він дуже терпів за останні роки свого життя. Вже потім, бувавши частіше, я дізнався, що вдачі Конисъкий був веселої, жартівливої, насмішкуватої, балакучий $і$ иікавий розмовник, який залюбки ділився своїм запасом, здобутим за багатого на пригоди й зустрічі життя»[2, с. 374]. Далі С. Єфремов робить акцент на звичці Кониського вечори проводити дома: «Вечорами він не виходив нікуди, зате у його можна було неодмінно спіткати когосъ із киян $i$ приїжджих, людей усякого віку, становища й поглядів; рідко випадав такий вечір, коли Олександр Яковлевич сидів самотою, зате часто траплялося, що люде переходили десятками» [2, с. 374].

Мемуарист відзначав у Кониського невичерпну енергію і фанатичне служіння справі. Водночас він не оминув і протиріч цієї важливої в історії українства постаті: «Я шанував $i$ иінив у Конисъкому той величезний запас невичерпаної енергії й банатичного служіння рідній справі, $і$ в ивому, власне, бачив джерело $i$ його помилок та хиб, $i$ вони через те не діяли на мене одворотним способом. 3 другого боку, ие була величезна робоча сила, яка імпонувала саме тим, шо не могла хвилини пробути без руху, без роботи, вічно носилася з усякими планами і ї спитувалась доконати, вічно кипіла, як справжсня людина діла та ініціативи. Приниипіяльно він допускав компроміси, йшов на них $і$ иноді спотикався, $i$ це було повною супротилежністю твердій, стриманій приниипіальності Драгоманова» [2, с. 377].

Для С. Єфремова постать Кониського була великою, оскільки він багато знав і вмів надихати молодь на працю в ім'я майбутнього України: «Для мене було ие справжнне джсерело відомостей про українсъку справу та людей, школа живої роботи, місце, куди легко нести було свої молодечі мрї та плани. Конисъкий, не зважаючи на свою сиву голову, й сам легко запалюв/ав]ся ними, $i$ через те, може, й юнакам було легко з ним жити і пращювати» [2, с. 378]. Деталь - сива голова - лише посилювала роль старого письменника в спрямуванні молоді на роботу в ім'я майбутнього. 
У спогадах С. Єфремова репрезентовано розгорнутий портрет відомого українського історика Володимира Антоновича, який викладав на громадських зібраннях історію України. Задовго до особистого знайомства мемуарист чув про особисту скромність історика: «3 інтересом приглядавсь я до иіеї маленької постати, ще 3 більшим - слухав надзвичайно прозорого, але глибокого викладу його історії, в якій він своїм звичайним тихим голосом давав квінтесенцію свого великого наукового надбання й життевого досвіду. Постать це була справді на диво скромна, але не тією свідомою скромністю, що знає собі иіну й немов аж трохи нею афішується, - ие була органічна скромність, яка не могла інакше поводитись, як поводиласъ. Наші уваги й запити, часто наївні й недоречні, він приймав так серйозно i так одповідав на них, що видно було: не з самоӥ ввічливості це робить, а з певного педагогічного переконання» [2, с. 378]. Важливою деталлю портрета Антоновича є його очі, про які С. Єфремов пише докладно, виділяючи на тлі обличчя: «Але що найбільше вражало на його досить ординарному обличчі з густою мужицькою чуприною, то ие очі - великі, сірі, променисті, для них, здавалося, не було перешкод, вони наскрізь бачили все, що попадало в поле їхнвого погляду, хоча б $і$ десятвма мурами сховане. Для очей иих не було труднощів. Скільки разів траплялося, що становище безвихідне, ради немае, - $i$ от характерний рух очима, ніби вони якось напружуються повернутись коло невидимої орбіти, i тихий спокійний голос подае раду, але таку, од якої справді кращого не вигадаєш» [2, с. 378-379]. Мемуарист, репрезентуючи портрет ученого, намагається зробити його психологічним, інтелектуальним: "Антонович умів "опасно ходити" $i$ зберіг себе в найлютіші часи гніту й реакиї̈, не жертвуючи своїми переконаннями. Легко зрозуміти, чому він користувавсь таким величезним впливом на людей $i$ чому слово його часто бувало законом: мудрість-бо справді часто говорила його устами. Інколи здавалось вона занадто великою обережсністю, політиканством, дипломатією, навіть полохливістю, $і$ на че нарікали нетерплячі гарячі люде. Але че була тільки мудрість людини, що бачить далі, ніж осередок. Головою об мур він ніколи не бився, ие не в його натурі було $і$ це було йому непотрібно, бо вмів він знайти в тому суиільному, здавалось, мурові таку щілину, крізъ яку й проносив свою контрабанду» [2, с. 379].

Висновки. Зображуючи розгорнуті портрети реальних людей, звичайних українських селян, батьків, а також відомих діячів української історії та культури, С.Єфремов намагався не лише відтворити неповторні риси їхньої зовнішності, а й розкрити роль 
у еволюції українства в умовах царської імперії: «Проходять одна по одній любі, дорогі тіні минулого. Померли люде. Рідко про них згадують. Але не померло те людсъке, що в них було, $i$ само про себе нагадуе. Не померли в нас, що нових дожили часів, їхні впливи, ті наслідки невмирущі їхнъого життя, трудного, невпокійного» $[2$, с. 381$]$.

Розгорнутий портрет зазвичай складається з декількох абзаців, а зосередженість його в одному місці тексту буває нечасто. У спогадах С. Єфремова портрет здебільшого постає статичним, концентрованим, він твориться на основі особистих вражень від спілкування автора 3 реальними героями, односельцями, членами родини, друзями, знайомими, але завжди доповнюється певними вагомими деталями, які роблять постать окремої особистості більш об'ємною, психологічно умотивованою. Творчу уяву, домисел і вимисел мемуарист намагається мінімізувати, ніби прагнучи, щоб читач мав можливість якомога повніше осмислити постать реальної особи, героя спогадів.

Перспективи подальших досліджень. Стаття є першою в циклі, присвяченому мемуарам С. Єфремова. У подальших публікаціях автор планує розглянути бачення відомим літературознавцем проблем історії видавничої справи та налагодження видання україномовної преси в умовах царської Росії кінця XIX - поч. ХХ ст.

\section{Література}

1. Галич А. О. Портрет у мемуарному та біографічному дискурсах: семантика, структура, модифікації : монографія. Старобільськ : Вид-во ДЗ “Луганський нац. ун-т імені Тараса Шевченка", 2017. 449 c.

2. Єфремов С. Щоденник. Про дні минулі (спогади). Київ: Темпора, 2011. $792 \mathrm{c}$. 